\title{
LIVER
}

\section{A role for thrombin in liver fibrosis}

\section{J Gillibert Duplantier, L Dubuisson, N Senant, G Freyburger, I Laurendeau, J-M Herbert, A Desmoulière, J Rosenbaum}

Background/Aim: Several lines of evidence incriminate the serine proteinase thrombin in liver fibrogenesis either through its procoagulant function or its signaling via cell-surface receptors. The aim of this study was therefore to evaluate the effect of thrombin inhibition on experimental liver fibrosis.

Methods: Fibrosis was induced in rats by administration of $\mathrm{CCl}_{4}$ for either three or seven weeks. Oral administration of the thrombin antagonist SSR1 82289 started one week after the start of $\mathrm{CCl}_{4}$ intoxication.

See end of article for authors' affiliations

....................

Correspondence to: Dr J Rosenbaum, GREF, INSERM E362, Université Bordeaux 2, 146 rue Léo Saignat, 33076 Bordeaux, France; jean.rosenbaum@ gref.u-bordeaux2.fr

Accepted for publication 27 April 2004 Fibrosis and the area occupied by alpha smooth muscle actin (ASMA) positive cells were quantified with histomorphometry. Expression of fibrosis related genes was measured by real time RT-PCR.

Results: After three weeks of $\mathrm{CCl}_{4}$, treatment with SSR182289 did not significantly decrease the area of fibrosis but significantly decreased the area of ASMA positive cells by $22 \%(p=0.03)$ and the expression of TIMP- 1 mRNA by $52 \%(p=0.02)$. There was no effect on gene expression of collagen I, MMP-2, or TIMP-2. After seven weeks of $\mathrm{CCl}_{4}$, treatment with SSR 182289 resulted in a significant decrease in fibrosis $(-30 \%, p=0.04)$ and ASMA positive areas $(-35 \%, p=0.05)$. SSR 182289 alone had no effect on the measured parameters. Additionally, it did not alleviate the acute toxicity of $\mathrm{CCl}_{4}$ as shown by measuring levels of serum aminotransferases and the area of necrosis.

Conclusions: These data provide evidence that thrombin antagonism can reduce liver fibrogenesis. The early effect of SSR182289 on ASMA and TIMP-1 expression suggests that it is beneficial in reducing fibrogenic cell activation. iver fibrosis is the main complication of chronic liver disease and leads eventually to cirrhosis. It is charac-terised by an excessive deposition of extracellular matrix components in the liver parenchyma. Synthesis of extracellular matrix components is performed by fibrogenic cells that derive from the activation of quiescent precursors such as hepatic stellate cells and portal fibroblasts.

During the past decade, a lot of attention has been given to the stimuli responsible for fibrogenic cell activation in the liver and a major focus has been on growth factors and oxidant stress. ${ }^{1}$ The role of the coagulation cascade has been suggested by various observations but has not been formally proved. Activation of coagulation classically proceeds through binding of activated factor VII to the transmembrane protein tissue factor. This will allow cleavage of factor X to Xa. Factor $\mathrm{Xa}$, in the presence of calcium and of factor Va will cleave prothrombin to thrombin. Thrombin is responsible for the conversion of fibrinogen to fibrin. Neubauer et al have shown that fibrin accumulates in the liver during acute as well as chronic experimental liver injury. ${ }^{2}$ Similar results have been observed in models of pulmonary fibrosis. However it was reported that a total deficiency of fibrinogen did not modify the extent of bleomycin induced lung fibrosis. ${ }^{34}$ Such data have not been clearly reported in the liver although there is suggestion that mice deficient in fibrinogen are not protected against the acute or chronic effects of carbon tetrachloride. ${ }^{5}$ Recently, it was observed that thrombotic risk factors were frequently observed in patients with chronic hepatitis B or C and that patients with more than one risk factor had on average more severe fibrosis. ${ }^{6}$ The rate of fibrosis progression is also higher in hepatitis $\mathrm{C}$ patients that carry the prothrombotic factor $\mathrm{V}$ Leiden mutation. ${ }^{7}$

There are at least two mechanisms through which thrombin generation could be involved in fibrogenesis. Firstly, clot formation by itself leads to flow disturbance and local hypoxia which is a cofactor for fibrosis. ${ }^{8}$ Secondly, thrombin signals via specific cellular receptors to regulate functions associated with tissue remodeling. ${ }^{9-11}$ Thrombin binds to several receptors that belong to the family of protease activated receptors (PAR). ${ }^{12}$ The thrombin receptor PAR-1 is upregulated in human liver during acute and chronic injury. ${ }^{13}$ It has been reported that thrombin stimulates the proliferation of rat $^{14}$ and human ${ }^{15}$ hepatic stellate cells. Thrombin also upregulates collagen synthesis in rat stellate cells. ${ }^{16}$

It has been shown that direct inhibition of thrombin with a synthetic antagonist decreased lung collagen accumulation in experimental pulmonary fibrosis. ${ }^{17}$ There are no clear data for liver fibrosis. Therefore, in this study, we investigated the effect of SSR182289, a synthetic thrombin inhibitor, ${ }^{18}{ }^{19}$ on liver fibrosis induced by carbon tetrachloride in the rat.

\section{MATERIAL AND METHODS}

\section{Animals and experimental design}

Male Wistar rats (Charles River, St Aubin-lès-Elbeuf, France) weighing 200-250 g were used in this study. The animals had free access to food and drinking water. This study was performed in accordance with the European Community Standards on the Care and Use of Laboratory Animals and approved by the Animal Care and Use Committee of the University of Bordeaux.

Fibrosis was induced by giving carbon tetrachloride $\left(\mathrm{CCl}_{4}\right.$, Sigma, St Quentin-Fallavier, France) mixed with olive oil (1:5) at $0.375 \mathrm{ml} / \mathrm{kg}$ body weight by gavage, three times a week on Monday, Wednesday, and Friday morning during three or seven weeks.

Abbreviations: aPTT, activated partial thrombin time; ASMA, alpha smooth muscle actin; $\mathrm{CCl}_{4}$, carbon tetrachloride; GAPDH, glyceraldehyde-3-phosphate-dehydrogenase; MMP, matrix metalloproteinase; PAR, protease activated receptor; TIMP, tissue inhibitor of matrix metalloproteinase. 
The thrombin antagonist used in this model (SSR182289) (S $^{19} \quad$ (Sanofi-Synthélabo-Recherche, ChillyMazarin, France) was administered daily on the evening by gavage, at the dose of $30 \mathrm{mg} / \mathrm{kg}$ body weight in distilled water. In order to avoid the risk of liver haemorrhage during the early phase of $\mathrm{CCl}_{4}$ intoxication where necrosis is prominent, SSR182289 administration was delayed until the second week of $\mathrm{CCl}_{4}$ treatment. Thus, the total length of SSR182289 treatment was either two or six weeks.

Control animals for $\mathrm{CCl}_{4}$ and SSR182289 received the respective solvents. Another group of rats received only SSR182289 at the same dose during two or six weeks.

Thus, four groups each including nine animals could be distinguished. Group I, olive oil and distilled water alone; group II, olive oil and SSR182289 alone; group III, $\mathrm{CCl}_{4}$ with distilled water; group IV, $\mathrm{CCl}_{4}$ with SSR182289.

Finally, in order to evaluate the initial toxicity of $\mathrm{CCl}_{4}$, a third group of animals received only two injections of $\mathrm{CCl}_{4}$ before sacrifice at day four.

Animals were sacrificed at the designated time points (96 hours, three and seven weeks). Liver samples were taken from several lobes and either snap frozen in liquid nitrogen, cryopreserved in optimal cutting temperature (OCT) compound (Sakura, Torrance, CA) and snap frozen in liquid nitrogen cooled isopentane, or fixed in buffered formalin. Serum and plasma samples were also collected.

\section{Liver function tests}

Routine liver function blood tests (bilirubin, alkaline phosphatase, and transaminases) were performed on an automated analyser in the biochemistry department of Pellegrin Hospital in Bordeaux.

\section{Blood clotting parameters}

Venous blood anticoagulated with sodium citrate was withdrawn in Vacutainer tubes (Becton Dickinson, Plymouth, UK). Plasma was centrifuged twice at $2500 \mathrm{~g}$ for 10 minutes and rapidly frozen at $-80^{\circ} \mathrm{C}$. Activated partial thrombin time (aPTT), was determined by a conventional method.

\section{Fibrosis assessment}

This was done, basically as previously described, using a histomorphometric method that measures the surface of a liver section occupied by fibrous areas. ${ }^{20}$ Sections $5 \mu \mathrm{m}$ thick from formalin fixed, paraffin embedded liver tissue were prepared and were stained with Sirius red (saturated picric acid in distillated water containing $0.1 \%(\mathrm{w} / \mathrm{v})$ Sirius red F3B (BDH Chemicals Ltd., Poole, UK) to allow visualisation of liver fibrosis. ${ }^{21}$ Slides were mounted with EUKITT (O Kindler GmbH \& Co, Freiburg, Germany) and examined with a Zeiss Axioplan 2 microscope (Carl Zeiss Microscopy, Jena, Germany) by light microscopy. All samples from a series of experiments were stained simultaneously and evaluated in a blinded fashion. Images were acquired with an AxioCam camera (Carl Zeiss Vision, Hallbergmoos, Germany) by means of the Axiovision image processing and analysis system (Carl Zeiss Vision) and quantitative data of the Sirius red staining were obtained using a computerised image analysis system (KS300, Carl Zeiss Vision). Sampling corresponded to three sections randomly taken from left, median, and right lobes. The analysis was performed on an average of 50 fields per section using the $\times 10$ objective. The whole surface of the sections was used for analysis with the exception of large centrolobular veins (diameter $\geqslant 150 \mu \mathrm{m}$ ) and large portal tracts. Fibrosis deposition was expressed as a percentage of Sirius red stained areas on the total area of the sections.

Immunolabeling for alpha smooth muscle actin (ASMA) was performed on serial sections of paraffin embedded hepatic tissue with a anti-ASMA monoclonal antibody (Dako A/S, Glostrup, Denmark, clone 1A4) diluted to 1/400, amplified with the EnVision+ system HRP detection kit (Dako A/S, Glostrup, Denmark) and revealed with liquid diaminobenzidine substrate (Dako A/S, Glostrup, Denmark). Results were analysed with the same method.

Quantitative measurements of collagen type I, MMP-2, TIMP-1, and TIMP-2 mRNAs by RT-PCR

After disruption and homogenisation in lysis buffer with the Mixer Mill MM300 (Qiagen SA, Courtaboeuf, France) of approximatively $50 \mathrm{mg}$ snap frozen liver, total RNA was isolated using the RNeasy Mini kit (Qiagen).

Transcripts of tissue inhibitor of matrix metalloproteinases (TIMP)-1, type I collagen $(\alpha(\mathrm{I}) 1$ chain), matrix metalloproteinase-2 (MMP-2), and TIMP-2 were quantified by a technique of quantitative RT-PCR, that has previously been described in detail. ${ }^{22}$ Each sample was normalised on the basis of its expression of the RPLP0 gene (also known as 36B4, encoding acidic ribosomal phosphoprotein P0).

\section{Radical scavenging activity}

Radical scavenging properties of SSR182289 were determined according to Blois ${ }^{23}$ by measuring reduction of the stable radical 1,1-Diphenyl-2-picrylhydrazyl (DPPH). Various concentrations of compounds diluted in dimethyl sulphoxide $(10 \mu \mathrm{l})$ were added to a $1 \mathrm{ml}$ solution of Tris/HCl (10 mM), $\mathrm{pH} \quad 7.2 / \mathrm{MeOH}(2 / 1, \mathrm{v} / \mathrm{v})$ containing DPPH $(20 \mu \mathrm{M})$. Absorbance at $517 \mathrm{~nm}$ was measured after 20 minutes.

\section{Statistical analysis}

All values are expressed as mean (standard deviation). Comparison of multiple means was performed with the Kruskall Wallis non-parametric test followed by the MannWhitney test, using the StatView 2.0 software (Abacus Concepts Inc, Berkeley, CA, USA).

\section{RESULTS}

\section{Effect of SSR 182289 on blood coagulation}

Control aPTT was $33 \mathrm{~s}$. One hour after the oral administration of $5,10,20$, or $30 \mathrm{mg} / \mathrm{kg}$ of SSR182289, aPTT increased to $44.5,50.7,55.7$, or $67.6 \mathrm{~s}$, respectively. The $30 \mathrm{mg} / \mathrm{kg}$ dose was then selected for further studies.

Effects of SSR 182289 on $\mathrm{CCl}_{4}$ induced initial toxicity Because the induction of $\mathrm{CCl}_{4}$ induced fibrosis depends on the initial induction of hepatocyte necrosis, we examined the effect of SSR182289 on the toxicity of $\mathrm{CCl}_{4}$. For that purpose, two groups of six rats treated with two administrations of $\mathrm{CCl}_{4}$ with or without two administrations of SSR182289 were killed 24 hours after the second $\mathrm{CCl}_{4}$ dose and evaluated for acute toxicity of $\mathrm{CCl}_{4}$ by serum tests and measurement of the area of necrosis on liver sections. As shown in table 1 , treatment with $\mathrm{CCl}_{4}$ resulted in an increase in the serum level of transaminases. Although there was a trend towards higher values in animals receiving the thrombin antagonist, the differences were not significant. As expected, treatment with $\mathrm{CCl}_{4}$ induced a significant centrolobular necrosis as shown on tissue sections. The necrosis area was however not statistically different between the two groups.

In addition, SR182289 did not display any antioxidant ability in a DPPH scavenging assay ( $1 \%$ inhibition, data not shown). The same assay clearly demonstrated the expected antioxidant activity of BHT and vitamin $\mathrm{E}^{2425} \quad\left(\mathrm{IC}_{50}=4\right.$ (SD 0.8) and 6 (SDl.4) $\mu \mathrm{M}$ respectively).

\section{Vital parameters and liver function tests}

After three weeks of $\mathrm{CCl}_{4}$, liver weight increased significantly as shown by the increase in liver weight to body weight ratio. 
Table 1 Liver function tests and area of necrosis in rats after 96 hours of $\mathrm{CCl}_{4}$ treatment with or without SSR 182289

\begin{tabular}{llll}
\hline Treatment & $\begin{array}{l}\text { Aspartate } \\
\text { aminotransferase } \\
\text { (IU/I) }\end{array}$ & $\begin{array}{l}\text { Alanine } \\
\text { aminotransferase } \\
\text { (IU/I) }\end{array}$ & $\begin{array}{l}\text { Necrosis } \\
\text { area (\%) }\end{array}$ \\
\hline $\mathrm{CCl}_{4}$ & $255.8(87.0)$ & $117.2(65.7)$ & $10.2(4.8)$ \\
$\mathrm{CCl}_{4}+\mathrm{SSR} 182289$ & $346.2(194.0)$ & $206.4(149.8)$ & $11.9(5.0)$ \\
\hline
\end{tabular}

Groups of six rats were treated with two administrations of $\mathrm{CCl}_{4}$ with or without two administrations of SSR 182289 and were killed 24 hours after the second $\mathrm{CCl}_{4}$ dose. Values are mean (standard deviation). No difference reached statistical significance.

Treatment with SSR182289 significantly decreased this ratio (table 2). Treatment with $\mathrm{CCl}_{4}$ resulted in increased values of serum transaminases and alkaline phosphatase. The administration of SSR182289 did not significantly decrease these parameters (table 2).

After seven weeks of $\mathrm{CCl}_{4}$, no clinical or biological parameter was significantly different between rats receiving or not SSR182289 (table 3).

No bleeding episode was observed during the course of these experiments.

\section{Fibrosis measurement}

$\mathrm{CCl}_{4}$ treatment for three weeks induced fibrosis deposition predominantly located around centrolobular hepatic veins, as shown by Sirius red staining (fig $\mathrm{lC}$ ). The area of fibrosis increased about tenfold from 0.285 (SD 0.05 ) \% of field area in control animals which received only olive oil (fig IA and B), to 2.62 (SD 0.65 ) \% in $\mathrm{CCl}_{4}$ treated animals.

SSR182289 administered alone had no effect on the fibrosis area (0.296 (SD 0.04) \%). Treatment with SSR182289 together with $\mathrm{CCl}_{4}$ slightly decreased the fibrosis area to 2.26 (SD 0.49) \% (fig $\mathrm{lG}$ ). This decrease did not however reach statistical significance.

ASMA staining was restricted to vessel walls as expected in control animals (fig $2 \mathrm{~A}$ and $\mathrm{B}$ ). Following $\mathrm{CCl}_{4}$ treatment, many ASMA positive cells were found in the diseased areas around centrolobular veins. Concurrent treatment with SSR182289 resulted in a significant $22 \%$ relative decrease in the ASMA positive areas (from 3.71 (SD 1.11) \% in the $\mathrm{CCl}_{4}$ group down to 2.89 (SD 0.65) \% in the $\mathrm{CCl}_{4}+\mathrm{SSR} 182289$ group $(\mathrm{p}=0.03)$ (fig $2 \mathrm{C}, \mathrm{D}, \mathrm{G})$

The longer, seven weeks $\mathrm{CCl}_{4}$ treatment induced a more severe fibrosis with larger septae arising from the hepatic veins that sometimes encircled nodules as shown on Sirius

Table 2 Vital parameters and liver function tests in rats after 3 weeks of treatment

\begin{tabular}{|c|c|c|c|c|}
\hline Parameters & Control & SSR 182289 & $\mathrm{CCl}_{4}$ & $\mathrm{CCl}_{4}+\mathrm{SSR} 182289$ \\
\hline Body weight (g) & $\begin{array}{l}374.4 \\
(29.1)\end{array}$ & $\begin{array}{l}354.9 \\
(15.7)\end{array}$ & $\begin{array}{l}325.8 \\
(24.3)\end{array}$ & $\begin{array}{l}317.2 \\
(12.8)\end{array}$ \\
\hline Liver weight (g) & $\begin{array}{l}14.4 \\
(2.4)\end{array}$ & $\begin{array}{l}13.5 \\
(0.9)\end{array}$ & $\begin{array}{l}15.3 \\
(2.5)\end{array}$ & $\begin{array}{l}13.2 \\
(1.3)^{*}\end{array}$ \\
\hline $\begin{array}{l}\text { LW:BW ratio } \\
(\times 100)\end{array}$ & $\begin{array}{l}3.8 \\
(0.4)\end{array}$ & $\begin{array}{l}3.8 \\
(0.1)\end{array}$ & $\begin{array}{l}4.7 \\
(0.6)\end{array}$ & $\begin{array}{l}4.2 \\
(0.3)^{*}\end{array}$ \\
\hline ASAT (IU/I) & $\begin{array}{l}89.9 \\
(17.5)\end{array}$ & $\begin{array}{l}113.2 \\
(29.0)\end{array}$ & $\begin{array}{l}269.3 \\
(133.9)\end{array}$ & $\begin{array}{l}205.0 \\
(98.2)\end{array}$ \\
\hline ALAT (IU/I) & $\begin{array}{l}48.6 \\
(8.2)\end{array}$ & $\begin{array}{l}46.2 \\
(6.6)\end{array}$ & $\begin{array}{l}285.7 \\
(173.0)\end{array}$ & $\begin{array}{l}202.6 \\
(129.2)\end{array}$ \\
\hline AP (IU/I) & $\begin{array}{l}168.1 \\
(47.6)\end{array}$ & $\begin{array}{l}188.1 \\
(63.8)\end{array}$ & $\begin{array}{l}300.0 \\
(50.2)\end{array}$ & $\begin{array}{l}247.8 \\
(68.9)\end{array}$ \\
\hline Bilirubin $(\mu \mathrm{M} / \mathrm{I})$ & $\begin{array}{l}2.6 \\
(1.0)\end{array}$ & $\begin{array}{l}2.3 \\
(0.7)\end{array}$ & $\begin{array}{l}2.4 \\
(1.6)\end{array}$ & $\begin{array}{l}2.7 \\
(0.7)\end{array}$ \\
\hline
\end{tabular}

Table 3 Vital parameters and liver function tests in rats after 7 weeks of treatment with or without SSR 182289

\begin{tabular}{lllll}
\hline Parameters & Control & SSR182289 & $\mathrm{CCl}_{4}$ & $\mathrm{CCl}_{4}+\mathrm{SSR} 182289$ \\
\hline Body weight & 404.3 & 388.6 & 341.1 & 315.3 \\
(g) & $(29.5)$ & $(28.5)$ & $(27.0)$ & $(24.5)$ \\
Liver weight & 14.5 & 14.0 & 14.1 & 13.5 \\
(g) & $(0.7)$ & $(1.9)$ & $(3.0)$ & $(1.4)$ \\
LW:BW ratio & 3.6 & 3.6 & 4.2 & 4.4 \\
$(\times 100)$ & $(0.4)$ & $(0.2)$ & $(0.7)$ & $(0.4)$ \\
ASAT (IU/I) & 94.3 & 112.9 & 440.0 & 919.0 \\
& $(5.8)$ & $(22.9)$ & $(264.8)$ & $(645.8)$ \\
ALAT (IU/I) & 50.7 & 48.7 & 286.4 & 505.0 \\
& $(8.3)$ & $(9.1)$ & $(209.8)$ & $(295.9)$ \\
AP (IU/I) & 144.2 & 116.3 & 315.2 & 485.6 \\
& $(40.0)$ & $(35.0)$ & $(160.0)$ & $(238.2)$ \\
Bilirubin & 2.6 & 3.3 & 4.9 & 4.7 \\
$(\mu \mathrm{M} / \mathrm{I})$ & $(0.9)$ & $(1.6)$ & $(5.6)$ & $(5.9)$ \\
\hline & & & & \\
& & & &
\end{tabular}

red stained sections (fig 1E). Treatment with SSR182289 resulted in a $30 \%$ decrease in fibrosis area from 6.56 (SD 2.77) \% of field area in $\mathrm{CCl}_{4}$ treated animals down to 4.56 (SD 1.65) \% ( $\mathrm{p}=0.04$ ) (fig $\mathrm{lF}$ and $\mathrm{G}$ ).

SSR182289 administered alone had no effect on the area of fibrosis $(0.58$ (SD 0.08) \%) compared with untreated controls (0.49 (SD 0.12) \%).

The ASMA positive area increased greatly after seven weeks of treatment with $\mathrm{CCl}_{4}$ from 0.55 (SD 0.08) \% in controls with olive oil (or 0.48 (SD 0.10 ) \% in rats with SSR182289 alone), up to 11.57 (SD 6.42) \% of field area (fig 2E). When the $\mathrm{CCl}_{4}$ treated animals also received SSR182289, the ASMA positive area was decreased by $35 \%$ down to 7.56 (SD 3.94) \% of field area $(p=0.05$ ) (fig $2 F$ and $G)$.

\section{Expression of fibrosis related genes}

Fibrosis deposition results from an imbalance between synthesis and degradation of its components. During liver fibrosis, failure of degradation is associated with an upregulation of the expression of the matrix metalloproteinase inhibitors TIMP-1 and TIMP-2. ${ }^{26}{ }^{27}$ We thus evaluated the mRNA levels of collagen $\alpha \mathrm{l}(\mathrm{I})$, a major component of liver fibrosis and of TIMP-1 and TIMP-2 by real time RT-PCR in total RNA extracted from rat livers. We also measured the levels of MMP-2 transcripts because although MMP-2 degrades several matrix components, MMP-2 overexpression is also associated with liver fibrosis. ${ }^{28}$ After three weeks, the administration of SSR182289 in $\mathrm{CCl}_{4}$ treated animals resulted in a significant $52.0 \%$ decrease in TIMP-1 expression $(\mathrm{p}=0.02)$ (fig 3$)$. On the other hand, whereas expression of transcripts for type I collagen, MMP-2, and TIMP-2 greatly increased with $\mathrm{CCl}_{4}$ treatment, they were not reduced by treatment with SSR182289 (fig 3). Administration of SSR182289 alone had no effect on gene expression.

\section{DISCUSSION}

In this study, we have evaluated the effect of chronic thrombin inhibition on the extent of fibrosis deposition in the $\mathrm{CCl}_{4}$ model of liver fibrosis in the rat. We show that a daily administration of SSR182289, a novel, selective, orally active synthetic thrombin inhibitor, ${ }^{18} 19$ decreased liver fibrogenesis induced by $\mathrm{CCl}_{4}$ after either three or seven weeks of intoxication. Although at three weeks the decrease in fibrosis deposition failed to reach statistical significance, there was already a significant decrease in the area occupied by ASMA positive cells and in TIMP-1 expression. This probably indicates a reduced extent of activation of fibrogenic cells in animals receiving the thrombin antagonist. After seven weeks of SSR182289, fibrosis area and ASMA positive 



Figure 1 Staining of fibrosis with Sirius red. Representative sections from animals of every group: (A) control, (B) SSR 182289 for three weeks alone, (C) $\mathrm{CCl}_{4}$ for three weeks, (D) $\mathrm{CCl}_{4}$ with SSR 182289 for three weeks, (E) CCl for seven weeks, (F) CCl 4 and SSR 182289 for seven weeks. (G) Values for individual animals. Note that although there were nine animals per group, some points are not visible because of superimposition.

area were both significantly reduced in animals treated with the thrombin antagonist. Inhibition of thrombin has been shown to offer protection against the acute toxicity of lipopolysaccharide to the liver. ${ }^{29}$ It is thus important to stress that SSR182289 had no protective effects in the early events of liver necrosis elicited by $\mathrm{CCl}_{4}$, which would have complicated the data interpretation. In addition, as the toxicity of $\mathrm{CCl}_{4}$ relies on oxidative stress, it was important to demonstrate that SSR182289 does not behave as an antioxidant in vitro.

Altogether, our data suggest that thrombin plays a detrimental role in chronic liver injury. This is also supported by recent data showing that mice genetically deficient in the fibrinogen related procoagulant Fgl2, an alternative prothrombin activator, are protected against liver injury from mouse hepatitis 3 virus; moreover, a high liver Fgl2

Figure 2 Immunostaining of alpha smooth muscle actin. Representative sections from animals of every group: (A) control, (B) SSR 182289 for three weeks alone, (C) $\mathrm{CCl}_{4}$ for three weeks, $\mathrm{CCl}_{4}$ with SSR182289 for three weeks, (E) CCl 4 for seven weeks, (F) CCl 4 and SSR182289 for seven weeks. (G) Values for individual animals. Note that although there were nine animals per group, some points are not visible because of superimposition.

expression was associated with fibrin deposition and severe forms of chronic viral hepatitis B in human. ${ }^{30}$

The mechanisms by which thrombin could aggravate liver diseases remain to be further elucidated. Because of the well known role of thrombin in fibrinogen cleavage, the first hypothesis to consider is the procoagulant function of thrombin. Fibrin deposition is indeed associated with both experimental and human liver fibrosis. It is not restricted to acute inflammatory liver disease but can also be found in chronic lesions. ${ }^{20}$ Fibrin deposition in vascular beds would lead to occlusive thrombi contributing to downstream liver injury. However, indirect data point against this mechanism. Firstly, bleomycin induced lung fibrosis, which shares many mechanistic features with experimental liver fibrosis, is not reduced in animals genetically deficient in fibrinogen. ${ }^{34}$ Secondly, mice with a combined deficiency in fibrinogen and plasminogen are quite sensitive to the profibrogenic 

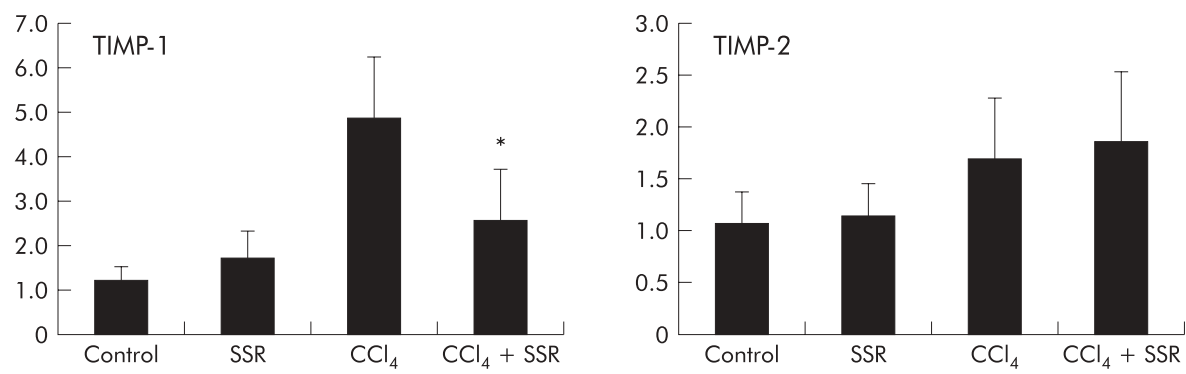

Figure 3 Expression of fibrosis related genes. The expression of the indicated transcripts was measured by real time RT-PCR on total liver RNA extracted from the livers of animals treated for three weeks in the indicated conditions. Transcripts levels were normalised on the basis of the expression of the RPLPO gene. Data are shown as mean (SEM) $(n=9)$ and are in arbitrary units. The asterisk indicates $p=0.02$. No other differences between the $\mathrm{CCl}_{4}$ and $\mathrm{CCl}_{4}+\mathrm{SSR} 182289$ groups were

statistically significant.

effects of $\mathrm{CCl}_{4}{ }^{5}{ }^{5}$ There are however no published data on liver fibrosis in animals with a single deficiency in fibrinogen. Other mechanisms must also be considered. Indeed, besides its procoagulant effect, thrombin also acts on cell surface receptors from the PAR family to induce intracellular signaling. Many signals relevant to liver fibrogenesis have been described. These include the stimulation of expression of the profibrogenic mediator connective tissue growth factor, ${ }^{10}{ }^{31}$ of type I collagen, ${ }^{9}$ or of TIMP- $1 .{ }^{32}$ Thrombin can also induce the activation of the proform of MMP- $2 .{ }^{33}$ More specifically, thrombin has been shown to stimulate proliferation $^{14}$ and matrix synthesis ${ }^{16}$ of cultured rat hepatic stellate cells and human liver myofibroblasts. ${ }^{15}$ Although there are no data for hepatic stellate cells, it has been shown that thrombin can induce the differentiation of lung fibroblasts into myofibroblasts. ${ }^{34}$ Finally, the thrombin receptor PAR-1 is overexpressed during human liver fibrogenesis in a location consistent with that of fibrogenic cells. ${ }^{13}$ Thus, circumstantial evidence suggests that the detrimental effects of thrombin on liver fibrogenesis could be mediated by its cell surface receptors. Our data provide a clue as to the mechanism by which thrombin inhibition may be protective. Indeed, we found that treatment with SSR182289 greatly reduced the expression of TIMP-1 transcripts. This appeared quite specific, as no differences were seen for other fibrosis related genes such as collagen $\alpha \mathrm{l}(\mathrm{I})$, MMP-2, or TIMP-2. These data are in keeping with the reported stimulating effect of thrombin on TIMP-1 expression in glomerular mesangial cells $^{32}$ and in human liver myofibroblasts ( $\mathrm{J}$ Gillibert Duplantier and J Rosenbaum, unpublished observations). TIMP-1 is a major actor of liver fibrogenesis. This has been notably shown in a study where overexpression of TIMP-1 by transgenesis strongly potentiated liver fibrosis. ${ }^{35}$ This is also suggested by the study by Raetsch $e a^{l^{36}}$ in bile duct ligated rats, where treatment with pentoxifylline had only a limited effect on liver fibrosis although it profoundly decreased expression of collagen I mRNA, most likely because it increased TIMP-1 expression. The deleterious effects of TIMP-1 may be related not only to its inhibitory effect on matrix degradation, but also to its antiapoptotic effect on fibrogenic cells. ${ }^{37}$ Thus, altogether, it is likely that the specific decrease in TIMP-1 expression may explain the antifibrotic effect of thrombin inhibition seen in this study.
While this manuscript was being submitted, Fiorucci et al showed that a PAR-1 antagonist strongly reduced liver fibrosis in the bile duct ligation model. ${ }^{38}$ In addition to thrombin, PAR-1 is also a receptor for other coagulation proteases including factor $\mathrm{Xa}^{39}{ }^{40}$ and activated protein $\mathrm{C}^{41}$ and it is thus possible that the benefits of antagonising PAR-1 relate in part to the inhibition of the signalling of these proteins. However, altogether, the case is strong for a role of coagulation proteases in liver fibrogenesis.

\section{ACKNOWLEDGEMENTS}

The authors want to thank the Comité de la Dordogne from the Ligue Nationale contre le Cancer and the Conseil Régional d'Aquitaine for supporting the project.

We thank the staff of the Biochemistry Department of Pellegrin hospital for performing liver function tests and Ivan Bièche for his help with real time RT-PCR.

\section{Authors' affiliations}

J Gillibert Duplantier, L Dubuisson, A Desmoulière, J Rosenbaum, GREF, INSERM E362, Université Bordeaux 2, Bordeaux, France J Gillibert Duplantier, L Dubuisson, N Senant, A Desmoulière, J Rosenbaum, IFR 66, Université Bordeaux 2, Bordeaux, France G Freyburger, Laboratoire d'Hématologie, Hôpital Pellegrin, Bordeaux, France

I Laurendeau, Laboratoire de Génétique Moléculaire UPRES 3618, Faculté des Sciences Pharmaceutiques et Biologiques de Paris, France J-M Herbert, Cardiovascular/Thrombosis Research Department, SanofiSynthélabo, Toulouse, France

\section{REFERENCES}

1 Friedman SL. Molecular regulation of hepatic fibrosis, an integrated cellular response to tissue injury. J Biol Chem 2000;275:2247-50.

2 Neubauer K, Knittel T, Armbrust T, et al. Accumulation and cellular localization of fibrinogen/fibrin during short-term and long-term rat liver injury. Gastroenterology 1995; 108:1 124-35.

3 Ploplis VA, Wilberding J, McLennan L, et al. A total fibrinogen deficiency is compatible with the development of pulmonary fibrosis in mice. Am J Pathol 2000;157:703-8.

4 Hattori N, Degen JL, Sisson TH, et al. Bleomycin-induced pulmonary fibrosis in fibrinogen-null mice. J Clin Invest 2000;106:1341-50.

5 Pohl JF, Melin-Aldana H, Sabla G, et al. Plasminogen deficiency leads to impaired lobular reorganization and matrix accumulation after chronic liver injury. Am J Pathol 2001;159:2179-86.

6 Papatheodoridis GV, Papakonstantinou E, Andrioti E, et al. Thrombotic risk factors and extent of liver fibrosis in chronic viral hepatitis. Gut 2003;52:404-9. 
7 Wright M, Goldin R, Hellier S, et al. Factor V Leiden polymorphism and the rate of fibrosis development in chronic hepatitis $C$ virus infection. Gut 2003;52:1206-10.

8 Corpéchot C, Barbu V, Wendum D, et al. Hypoxia-induced VEGF and collagen I expressions are associated with angiogenesis and fibrogenesis in experimental cirrhosis. Hepatology 2002;35:1010-21.

9 Chambers RC, Dabbagh K, McAnulty RJ, et al. Thrombin stimulates fibroblast procollagen production via proteolytic activation of protease-activated receptor 1. Biochem J 1998;333:121-7.

10 Chambers RC, Leoni P, Blanc-Brude OP, et al. Thrombin is a potent inducer of connective tissue growth factor production via proteolytic activation of protease-activated receptor-1. J Biol Chem 2000;275:35584-91.

11 Duhamel-Clérin E, Orvain C, Lanza F, et al. Thrombin receptor-mediated increase of two matrix metalloproteinases, MMP-1 and MMP-3, in human endothelial cells. Arterioscler Thromb Vasc Biol 1997;17:1931-8.

12 Coughlin SR. How the protease thrombin talks to cells. Proc Natl Acad Sci U S A 1999;96:1 1023-7.

13 Marra F, DeFranco R, Grappone C, et al. Expression of the thrombin receptor in human liver: up-regulation during acute and chronic injury. Hepatology 1998;27:462-71.

14 Marra F, Grandaliano G, Valente AJ, et al. Thrombin stimulates proliferation of liver fat-storing cells and expression of monocyte chemotactic protein-1: potential role in liver injury. Hepatology 1995;22:780-7.

15 Mallat A, Gallois C, Tao J, et al. Platelet-derived growth factor-BB and thrombin generate positive and negative signals for human hepatic stellate cell proliferation. Role of a prostaglandin/cyclic AMP pathway and cross-talk with endothelin receptors. J Biol Chem 1998;273:27300-5.

16 Gaca MD, Zhou X, Benyon RC. Regulation of hepatic stellate cell proliferation and collagen synthesis by proteinase-activated receptors. J Hepatol 2002;36:362-9.

17 Howell DC, Goldsack NR, Marshall RP, et al. Direct thrombin inhibition reduces lung collagen accumulation, and connective tissue growth factor mRNA levels in bleomycin-induced pulmonary fibrosis. Am J Pathol 2001;159:1383-95.

18 Berry CN, Lassalle G, Lunven C, et al. SSR182289A, a novel, orally active thrombin inhibitor: in vitro profile and ex vivo anticoagulant activity. $J$ Pharmacol Exp Ther 2002;303:1189-98.

19 Lorrain J, Millet L, Lechaire I, et al. Antithrombotic properties of SSR182289A a new, orally active thrombin inhibitor. J Pharmacol Exp Ther 2003;304:567-74.

20 Dubuisson L, Desmoulière A, Decourt B, et al. Inhibition of rat liver fibrogenesis through noradrenergic antagonism. Hepatology 2002;35:325-31.

21 Waldrop FS, Puchtler $\mathrm{H}$. Light microscopic distinction of collagens in hepatic cirrhosis. Histochemistry 1982;74:487-91.

22 Bieche I, Nogues C, Paradis V, et al. Quantitation of hTERT gene expression in sporadic breast tumors with a real-time reverse transcription-polymerase chain reaction assay. Clin Cancer Res 2000;6:452-9.

23 Blois $\mathbf{M}$. Antioxidant determination by the use of a stable free radical. Nature 1958;4617:1199-200.

24 Barclay L, Ingold K. Autoxidation of biological molecules. 2. The autoxidation of a model membrane. A comparison of the autoxidation of egg lecithin phosphatidylcholine in water and in chlorobenzene. J Am Chem Soc 1981; 103:6478-85.
25 Burton G Ingold K. Autoxidation of biological molecules. I. The antioxidant activity of vitamin $\mathrm{E}$ and related chain-breaking phenolic antioxidants in vitro. J Am Chem Soc 1981;103:6472-77.

26 Benyon RC, Iredale JP, Goddard S, et al. Expression of tissue inhibitor of metalloproteinases 1 and 2 is increased in fibrotic human liver. Gastroenterology 1996;1 10:821-31.

27 Herbst H, Wege T, Milani S, et al. Tissue inhibitor of metalloproteinase- 1 and -2 RNA expression in rat and human liver fibrosis. Am J Pathol 1997:150:1647-59.

28 Takahara T, Furui K, Funaki J, et al. Increased expression of matrix metalloproteinase-ll in experimental liver fibrosis in rats. Hepatology 1995;21:787-95

29 Pearson JM, Schultze AE, Schwartz KA, et al. The thrombin inhibitor, hirudin, attenuates lipopolysaccharide-induced liver injury in the rat. J Pharmacol Exp Ther 1996:278:378-83.

30 Marsden PA, Ning Q, Fung LS, et al. The Fgl2/fibroleukin prothrombinase contributes to immunologically mediated thrombosis in experimental and human viral hepatitis. J Clin Invest 2003;112:58-66.

31 Pendurthi UR, Allen KE, Ezban $M$, et al. Factor Vlla and thrombin induce the expression of Cyr6l and connective tissue growth factor, extracellular matrix signaling proteins that could act as possible downstream mediators in factor Vlla.tissue factor-induced signal transduction. J Biol Chem 2000;275: 14632-41.

32 Kaizuka M, Yamabe H, Osawa H, et al. Thrombin stimulates synthesis of type IV collagen and tissue inhibitor of metalloproteinases-1 by cultured human mesangial cells. J Am Soc Nephrol 1999;10:1516-23.

33 Galis ZS, Kranzhofer R, Fenton JW, et al. Thrombin promotes activation of matrix metalloproteinase-2 produced by cultured vascular smooth muscle cells. Arterioscler Thromb Vasc Biol 1997;17:483-9.

34 Bogatkevich GS, Tourkina E, Silver RM, et al. Thrombin differentiates normal lung fibroblasts to a myofibroblast phenotype via the proteolytically activated receptor- 1 and a protein kinase C-dependent pathway. J Biol Chem 2001;276:45184-92

35 Yoshiii H, Kuriyama S, Miyamoto Y, et al. Tissue inhibitor of metalloproteinases-1 promotes liver fibrosis development in a transgenic mouse model. Hepatology 2000;32:1248-54.

36 Raetsch C, Jia JD, Boigk G, et al. Pentoxifylline downregulates profibrogenic cytokines and procollagen I expression in rat secondary biliary fibrosis. Gut 2002;50:241-7.

37 Murphy FR, Issa R, Zhou X, et al. Inhibition of apoptosis of activated hepatic stellate cells by tissue inhibitor of metalloproteinase- 1 is mediated via effects on matrix metalloproteinase inhibition: implications for reversibility of liver fibrosis. J Biol Chem 2002;277:11069-76.

38 Fiorucci S, Antonelli E, Distrutti E, et al. PAR1 antagonism protects against experimental liver fibrosis. Role of proteinase receptors in stellate cell activation. Hepatology 2004;39:365-75.

39 Riewald M, Ruf W. Mechanistic coupling of protease signaling and initiation of coagulation by tissue factor. Proc Natl Acad Sci U S A 2001;98:7742-7.

40 Camerer E, Kataoka H, Kahn M, et al. Genetic evidence that proteaseactivated receptors mediate factor Xa signaling in endothelial cells. J Biol Chem 2002;277:16081-7.

41 Riewald M, Petrovan RJ, Donner A, et al. Activation of endothelial cell protease activated receptor 1 by the protein $C$ pathway. Science 2002;296:1880-2 